\title{
FLOODS IN CENTRAL, SOUTHWEST OKLAHOMA OCTOBER 17-23, 1983
}

By Leland D. Hauth

U.S. GEOLOGICAL SURVEY

Open-File Report 85-494

Oklahoma City, Oklahoma

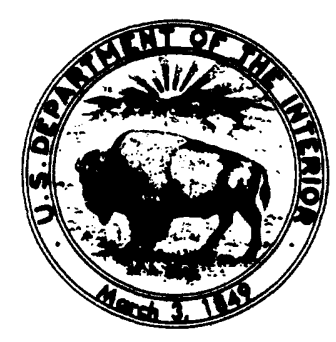




\title{
UNITED STATES DEPARTMENT OF THE INTERIOR DONALD PAUL HODEL, Secretary
}

\author{
GEOLOGICAL SURVEY \\ Dallas L. Peck, Director
}

For additional information write to:

District Chief

U.S. Geological Survey

Water Resources Division

Room 621, Old Post Office Building

215 Dean A. McGee Avenue

Oklahoma City. Oklahoma 73102

Telephone: (405) 231-4256
Copies of this report can be purchased from:

Open-file Services Section

Western Distribution Branch

U.S. Geological Survey

Box 25425, Federal Center

Lakewood, Colorado 80225

Telephone: (303) 844-4169 


\section{CONTENTS}

Page

Conversion of inch-pound units to International System of Units (SI).. Iv

Abstract......................................... 1

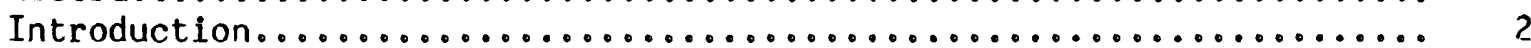

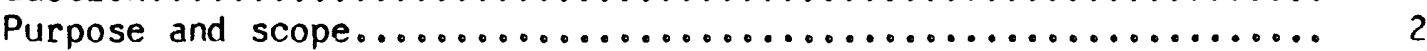

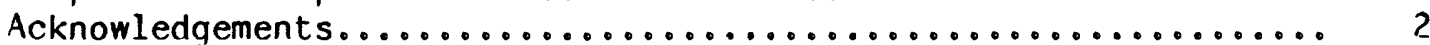

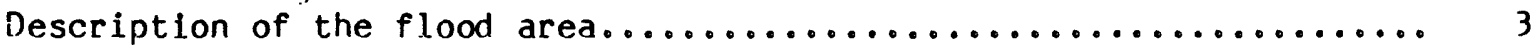

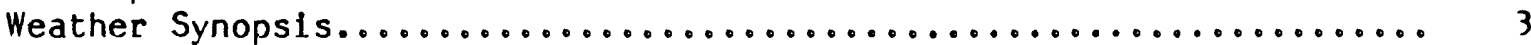

Description and measurement of floods...................... 8

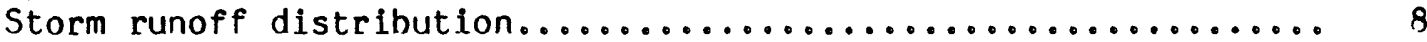

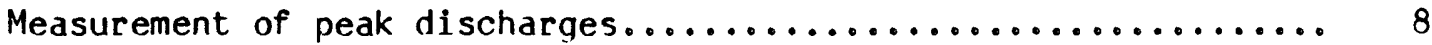

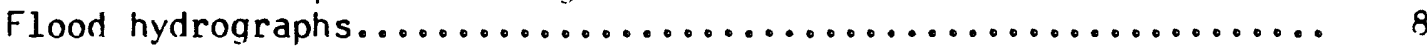

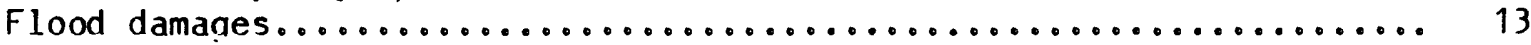

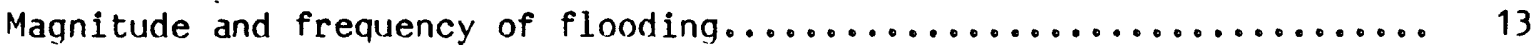

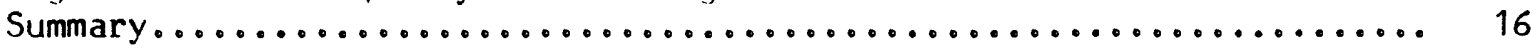

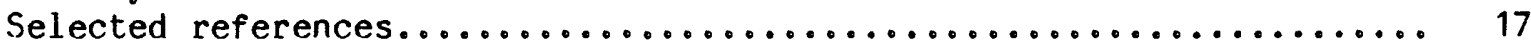

\section{ILLUSTRATIONS}

Figure 1. Location of flooding in Oklahoma, Octoher 17-23, 1983..... 4

2. Study area and location of flood-determination points...... 5

3. Mass rainfall curves for selected rain gages for the storm

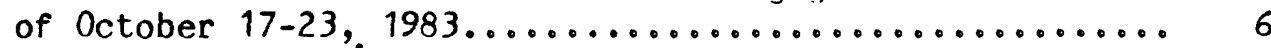

4. Map of total storm rainfall of nctober 17-23, 1983

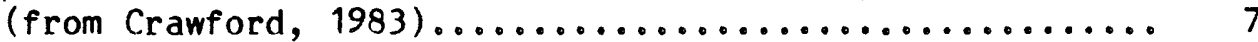

5. Discharge hydroqraph at U.S. Reological Survey qaqing station at Walnut Creek at Purcell, Oklahoma, flood

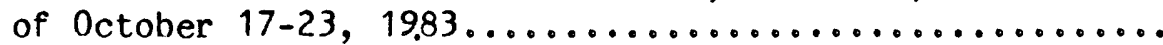

6. Discharqe hydrograph at 11.5 . Geological Survey gaging station on Deep Red Run at Randlett, Oklahoma, flond

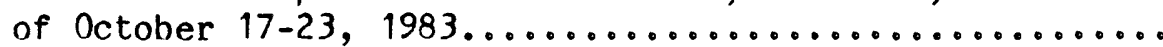

7. Discharge hydrograph at U.S. Geoloqical Survey aaqing station on Cottonwood Creek near Navina, Oklahoma, flood

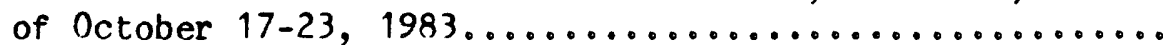

8. View looking south toward U.S. Highway 77 bridge over Walnut Creek at Purcell, Oklahoma, Octoher 20, 1983...... comparison of October 17-23, 1983, peak discharges to upper limits of known floods in 0klahoma-Kansas and in the United States............................

\section{TARLE}

Table 1. Summary of peak stages and discharges for fluods of

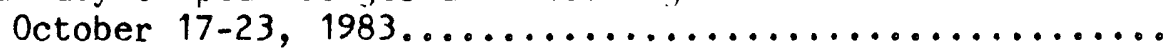


All units of measure used in this report are inch-pound units. The following factors may be used to convert inch-pound units to the International System of Units (SI).

Multiply inch-pound units

inches (in)

feet $(\mathrm{ft})$

miles (mi)

square miles $\left(\mathrm{mi}^{2}\right)$

acre-feet (acre-ft)

acre-feet (acre-ft)

cubic feet per second $\left(\mathrm{ft}^{3} / \mathrm{s}\right)$

qallons (qal)
By

25.4

0.3048

1.609

2.590 1,233

$1.233 \times 10^{-3}$

0.02832
To obtain SI units

millimeter $(\mathrm{mm})$

meter $(m)$

kilometer $(\mathrm{km})$

square kilometęr $\left(\mathrm{km}^{2}\right)$

cubic meter $\left(\mathrm{m}^{3}\right)$

cubic hectometer $\left(\mathrm{hm}^{3}\right)$

cubic meters per second

$$
\left(\mathrm{m}^{3} / \mathrm{s}\right)
$$

$3.785 \times 10^{-3}$ cubic meter $\left(\mathrm{m}^{3}\right)$

National Geodetic Vertical Datum of 1929 (NGVD of 1929): A geodetic datum derived from a general adfustment of the first order level nets of both the United States and Canada, formerly called "Mean Sea Level". 
FLOODS IN CENTRAL, SOUTHWEST OKLAHOMA OCTOBER 17-23, 1984

By Leland D. Hauth

\begin{abstract}
Storms of 0ctober 17-23, 1984 producer as much as 17 inches of rain as a result of Hurricane Tico. Rainfall amounts exceeded the 100-year, 24-hour storm frequency in some areas of the central and southwest parts of 0klahoma. An 11-county area experienced flooding with damages exceeding $\$ 12$ million. Peak discharges were determiner during and after the flood at IJ.S. Geolonical Survey gaging stations and one miscellaneous location. Streamflow in some areas exceeder the estimated 100-year flood. Flood hydroqraphs and rainfall mass curves are presented for gaging stations located in areas of areater precipitation.
\end{abstract}




\section{INTRODUCTION}

Outstanding floods along many major streams occurred in Oklahoma during October 17-23, 1983, as a result of the remnants of hurricane Tico. Storms moving across the State from southwest to northeast during the seven-day period produced from 10 to 17 inches of rainfall in the area. The area flooded includes many of the same counties designated as a drought area by Presidential declaration just prior to the flooding.

Record stages were recorded and flood discharges exceeding the 100-year flood were experienced at some locations. Direct measurements of discharge were made at many sites during the flood to establish the staqe-discharge relation or to verify a previously defined relation. Where possible, U.S. Geological Survey hydrologists made stream-flow measurements during flood peaks. Some gaging stations could not he reached following the flooding because of high water, requiring that peak flows be determined by indirect methods.

\section{Purpose and Scope}

This report has been prepared to provide peak staqe and discharge information collected in Oklahoma during the floods of Octoher 17-23, 1983.

Climatic data collected by the National Weather Service document the meteorological settings associated with the extreme amount and distribution of rainfall. Meteorological data presented in this report include storm-rainfall isohyetal maps and rainfall mass curves for selected locations within the area of flooding.

Streamflow data collected by the U.S. Geological Survey include rates of flow, peak stages and discharges. Analysis of these data includes discharge hydrographs and comparison of measured peak discharges to historic floodina. Elevations are referred to National Geodetic Vertical Datum (NGVD).

\section{Acknowledgments}

Total storm-rainfall isohyetal maps, daily rainfall totals and single storm event totals, rainfall mass curves at selected locations, and information on weather system movements were furnished by Eldon Beard of the Oklahoma City office of the National Weather Service.

Information on flood damages were ohtained from the Federal Emergency Management Agency offices in Denton, Texas, the U.S. Small Business Administration, the U.S. Farm Home Administration, and the Flood Insurance Administration as reported to the Federal Emergency Management Aqency of Denton, Texas. The photograph of Walnut Creek at Purcell was obtained from "The Purcell Register", Purcell, OkIahoma. 


\section{DESCRIPTION OF THE FLOOD AREA}

The area affected by the October 17-23, 1983 flood included parts of north-central Texas and central and southwestern 0klahoma. This report, however, describes only that flooding which occurred in central and southwestern Oklahoma (fig. 1). Major flooding involved about one-fourth of the State and included the main stem of the Washita River, the Little Washita River, the Walnut Creek basin, the Cache Creek basin, the upper reaches of Little River, the lower reaches of the North Fork Red River, and Deep Fork.

Urban areas most affected by the flood waters within the area included Purcell, Oklahoma City, Guthrie, Chickasha, and Lawton.

Peak flows were determined at U.S. Geological Survey stream-gaging stations and document the extent of flooding both in areal coverage and magnitude. Figure 2 shows the location of stream-gaging stations used to define the extent of flooding.

\section{WEATHER SYNOPSIS}

A weak cold front moved into northwestern Oklahoma on Sunday, October 16 during a time when a low level trough moved across northwest Texas into 0klahoma during the nighttime hours between the 16th and 17th. These systems caused rain showers and thundershowers over much of the area with the precipitation ending in eastern portions of Oklahoma on the night of the 17th. The cold front then became stationary, extending from the Red River near south-central Oklahoma to southwestern Arkansas. Moisture continued to be fed northward from the Gulf of Mexico toward the frontal system while hiah level moisture was being brought in from the remains of the Pacific ncean Hurricane "Tico". A series of minor low pressure troughs moved across the area during 0ctober 19-21 causing widespread rain with the heaviest amounts occurring on the 19th and 20th. As the remains of Hurricane Tico moved northeastward across Oklahoma, precipitation ended (Crawford 1983). The highest rainfall amounts were recorded at the U.S. Department of Agriculture Research Station near Rush Springs (17 inches) and Great Plains Apiaries near Chickasha, Oklahoma (over 14 inches) in the central and southwestern part of the State. Rainfall amounts and intensities are shown for these locations fiqure 3. Total storm rainfall is shown on the map of figure 4. Rainfall accumulations were recorded continuously at many locations in the flood area.

Based on rainfall-frequency relations developed by Hershfield (1961), the October 1983 rainfall exceeded the 100-year, 24-hour storm frequency $(8.5$ inches in 24 hours) near Rush Springs and equaled that frequency at the Great Plains Apiaries station. These stations are used here as an example of the overall storm intensities in the areas of greater precipitation depth. 


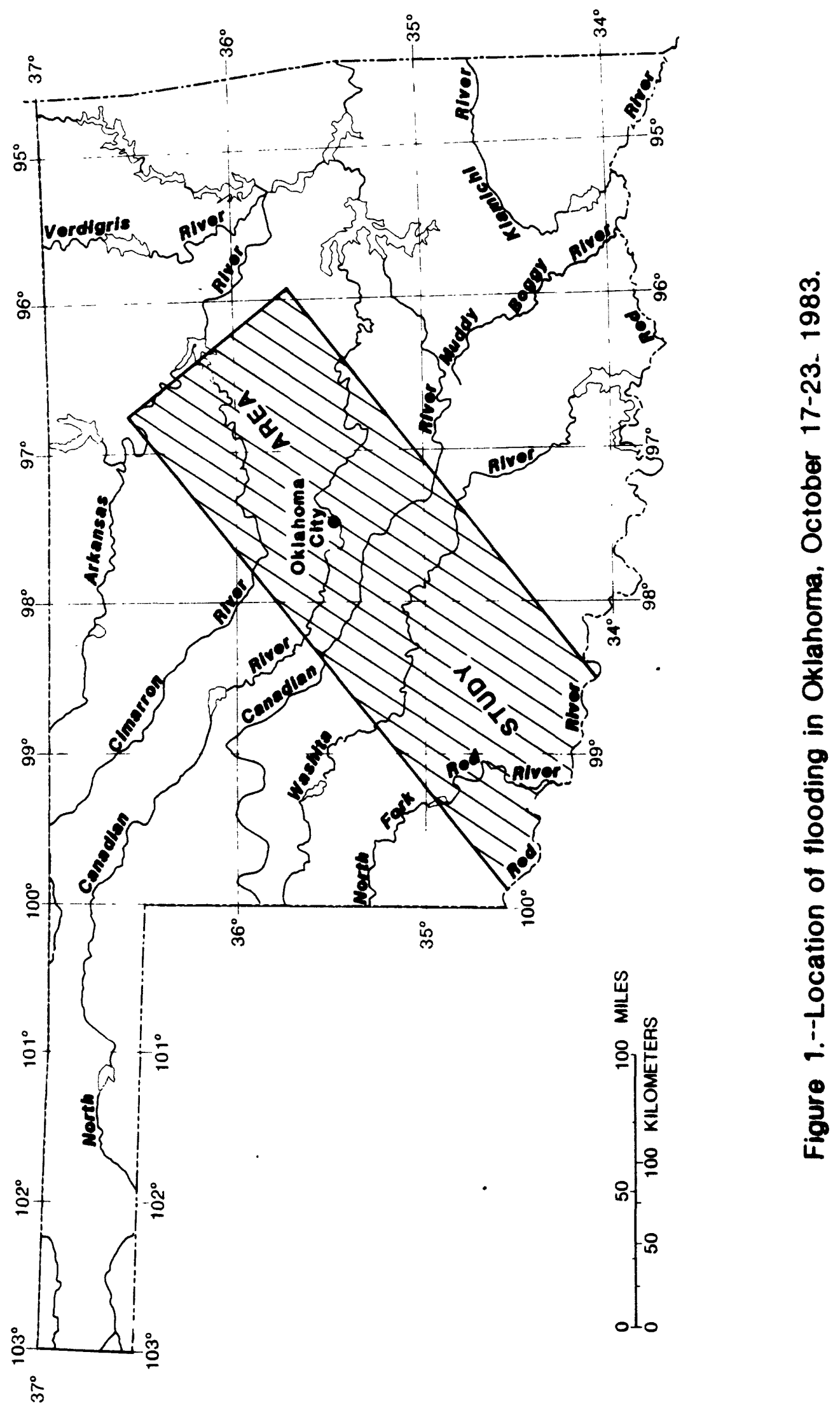




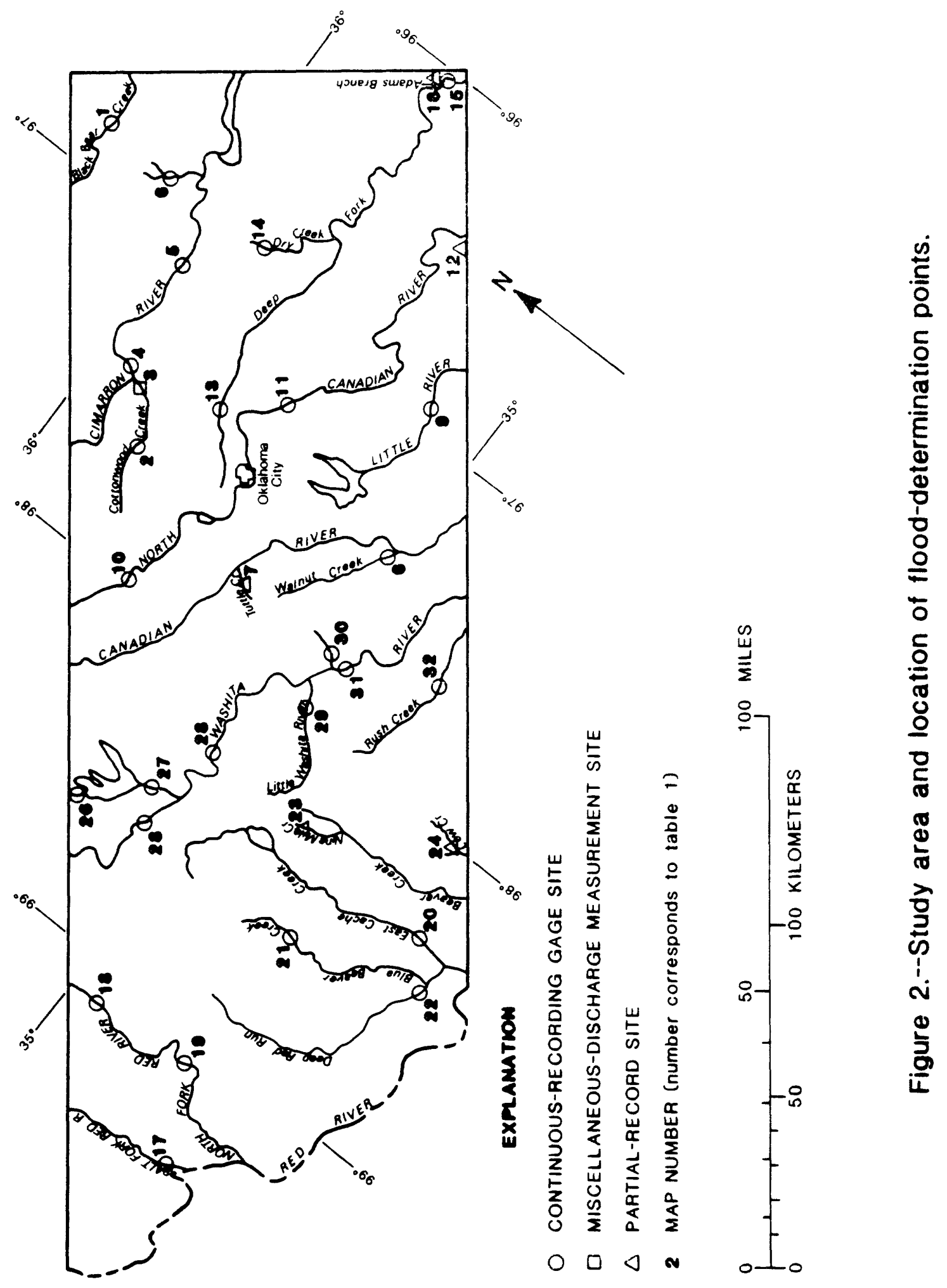



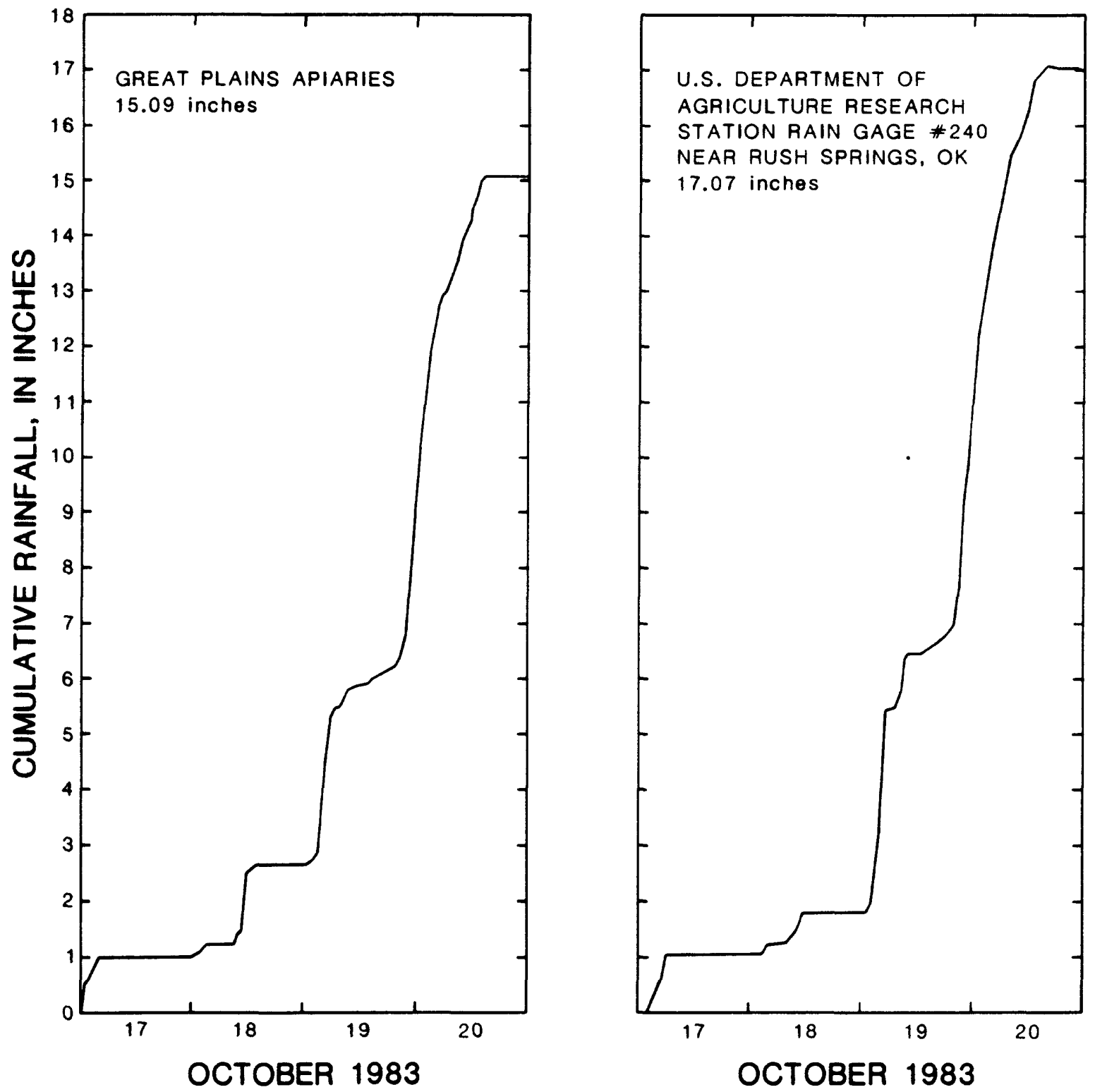

Figure 3.--Mass rainfall curves for selected rain gages for the storm of October 17-23, 1983. 


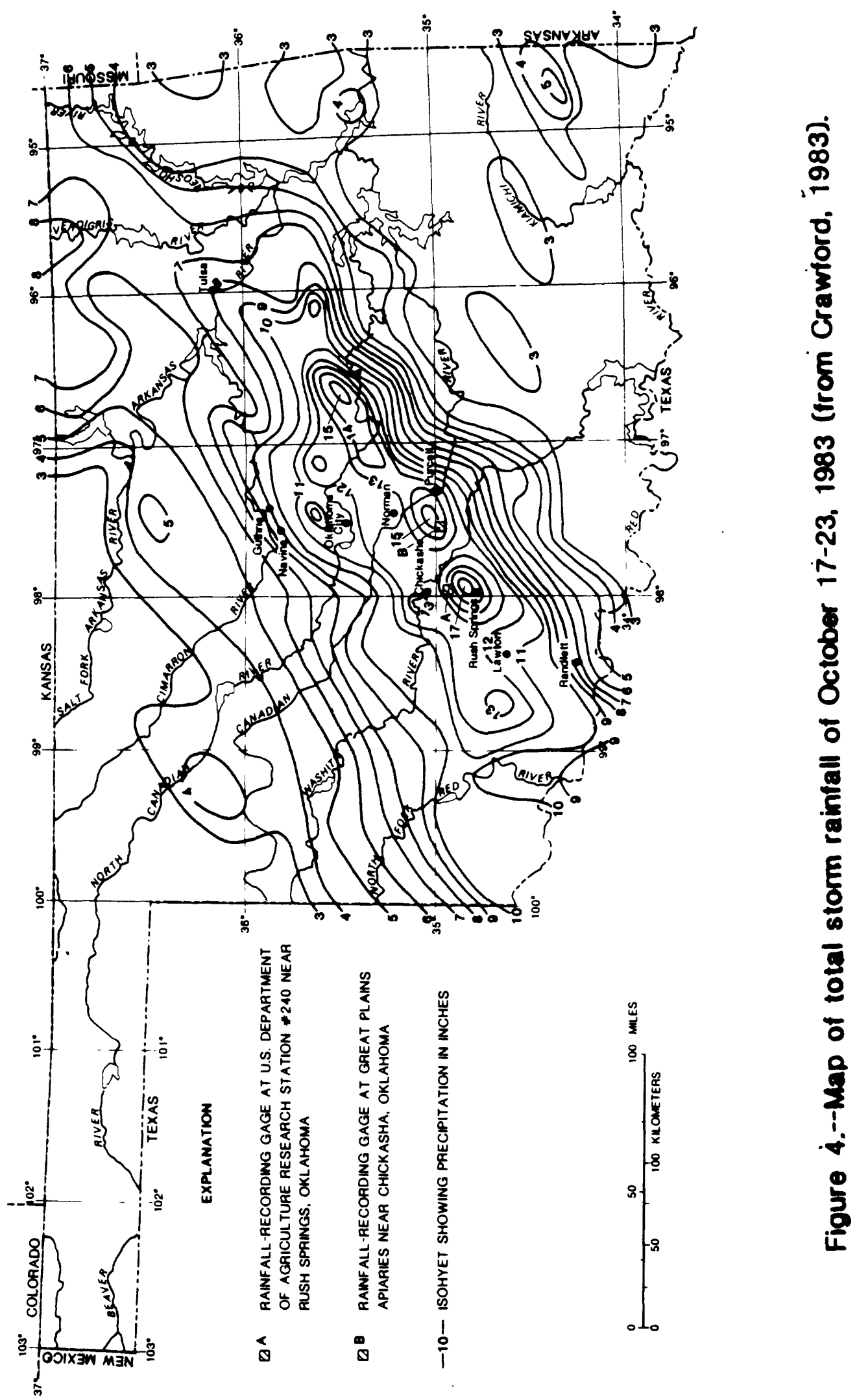




\section{DESCRIPTION AND MEASUREMENT OF FLOODS}

\section{Storm Runoff Distribution}

Stream-qaging stations located within the flood area recorded flow data from drainage areas ranging from 5.9 to 17,852 square miles. Stations recording runoff from drainaqe areas less than 50 square miles within locations of heavy rainfall (greatest storm totals) indicate more discharge per square mile than stations sampling drainage areas areater than 50 square miles. However, high rates of runoff were noted along the main stem of the Washita River, but because of flow regulation by storage reservoirs throughout the basin, unit runoff (discharge per square mile) is not shown. Storm runoff may have been greater in urbanized areas because runoff was not affected by antecedent drought conditions. Unit runoff was not determined in the ubanized areas.

\section{Measurement of Peak Discharqes}

Hydrologists were in the areas of highest reported rainfall heginning October 19 and began measuring streamflow throughout the range of flood discharges at selected gaging stations. Although stage-discharge relations were previously defined at most gaging-station locations, floodflows at some sites were higher than any previous flood and, therefore, were given priority. In some cases, direct measurements could not be obtained and indirect methods were used. All indirect measurements were made using methods described in "Techniques of Water Resources Investiqations of the U.S. Geological Survey", (Dalrymple and Benson, 1967; Matthai, 1967; Bodhaine, 1968; Hulsing, 1968). Data from staqe-discharge relations as defined by direct or indirect methods were obtained from 31 qagina stations and one miscellaneous site and are tabulated in table 1 . Fiqure 2 shows the location of the sites and the drainage system.

Table 1 lists the discharge measurement sites in downstream order, size of drainage area in square miles, period of record (water year) (0ctober 1 to September 30), date of maximum stage (in feet above NGVD of 1929) and maximum discharge for both the October 17-23, 1983, flood and any previously known flood for each site. Also included is the unit runoff of the 0ctober 1983 flood at each site computed from the ratio of peak discharge to the drainage area above the site, and the recurrence interval of the October 1983 flood in years.

Peak discharge at the Deep Fork near Beggs gage was recorded on October 25, about 4-5 days later than other flood crests, and is included to show the effect of storm movement on flood discharge as it moved to the north and east and dissipated in strenath.

\section{Flood Hydrographs}

Figures 5-7 show flood hydrographs from stream-gaging stations located in areas having the highest rainfall and runoff amounts. Discharge hydrographs are developed from stream-stage records and from previously defined relationships between stage and stream discharge at each site. 


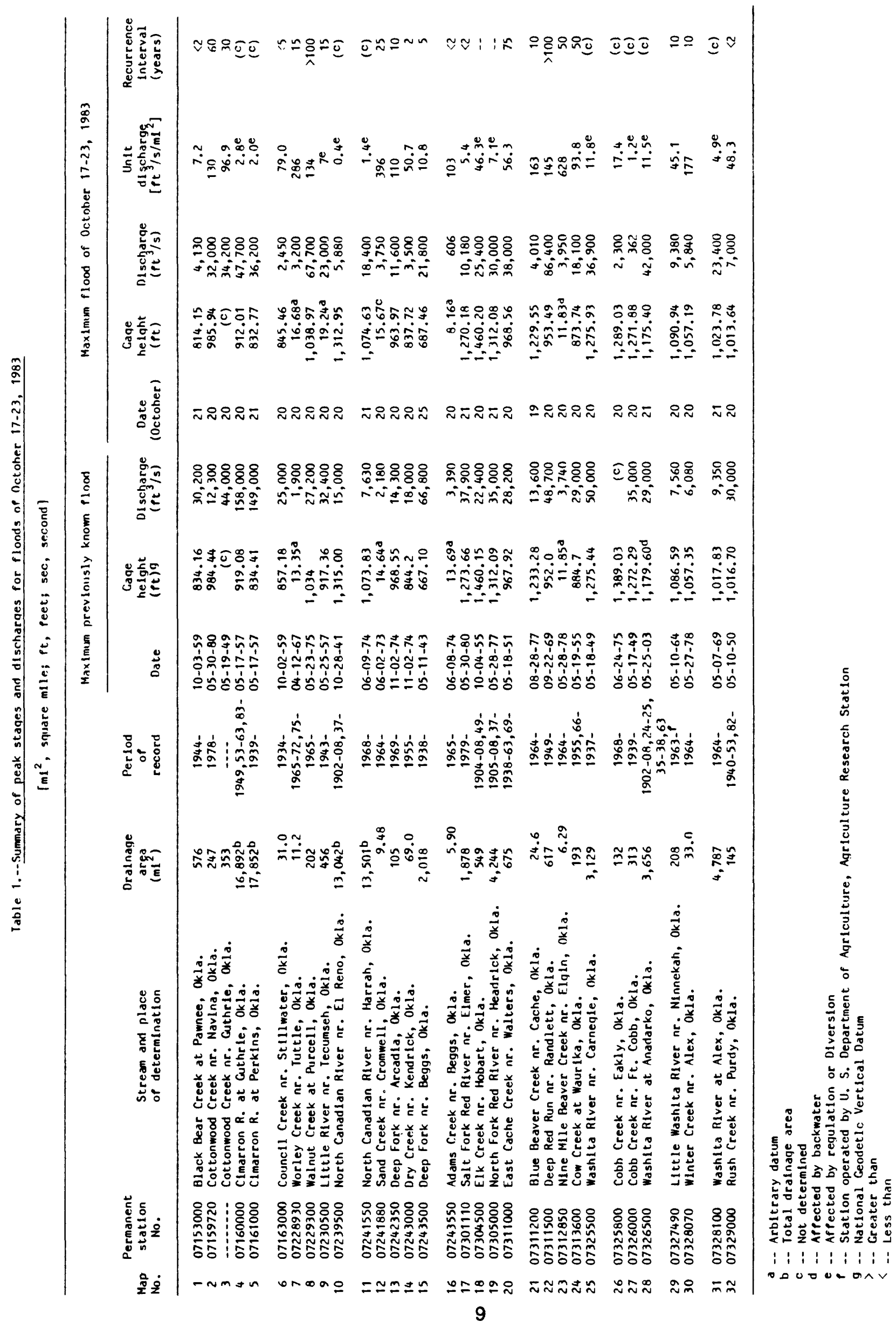




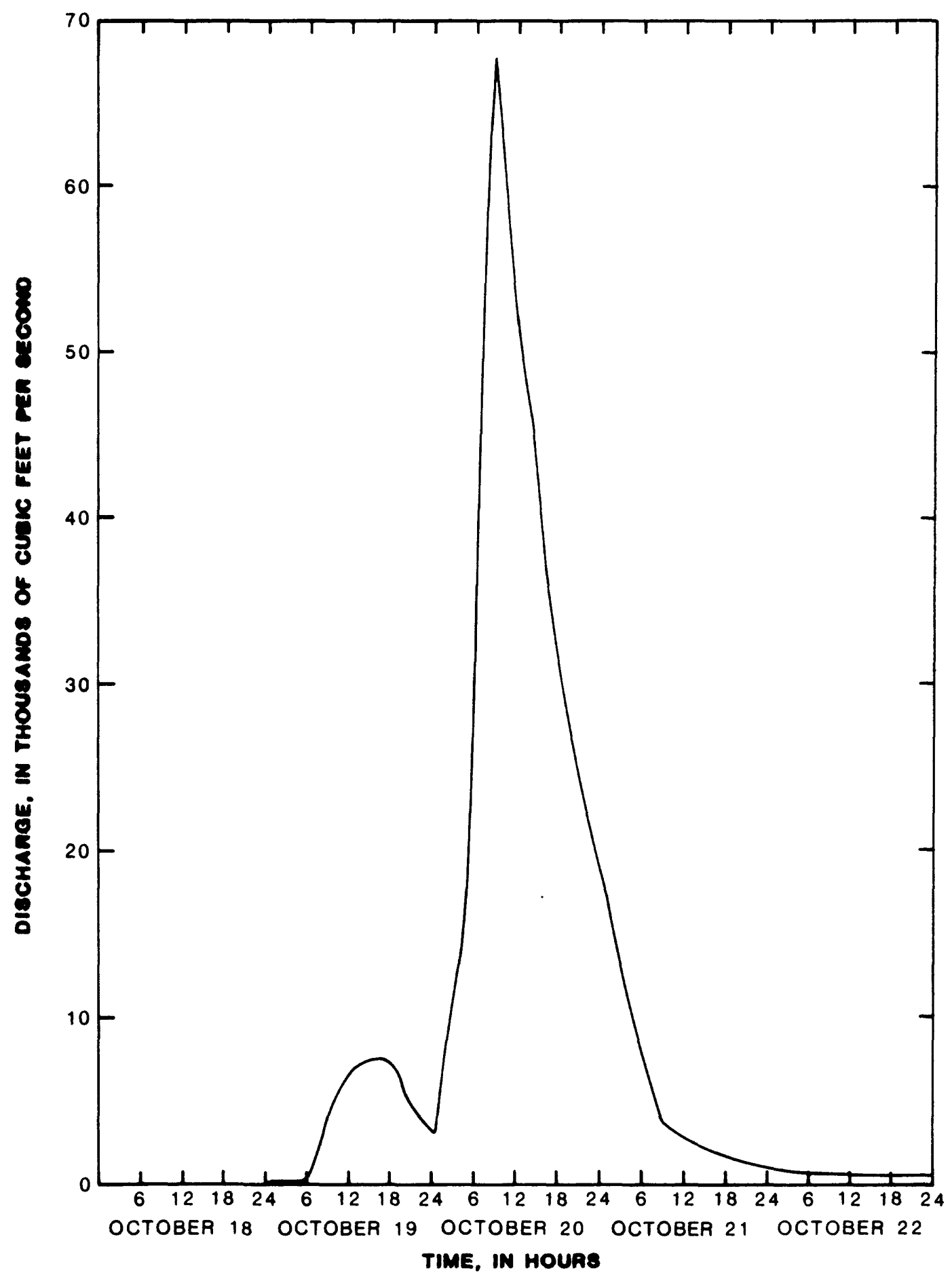

Figure 5.--Discharge hydrograph at U.S. Geological Survey gaging station at Walnut Creek at Purcell, Oklahoma, flood of October 17-23, 1983. 


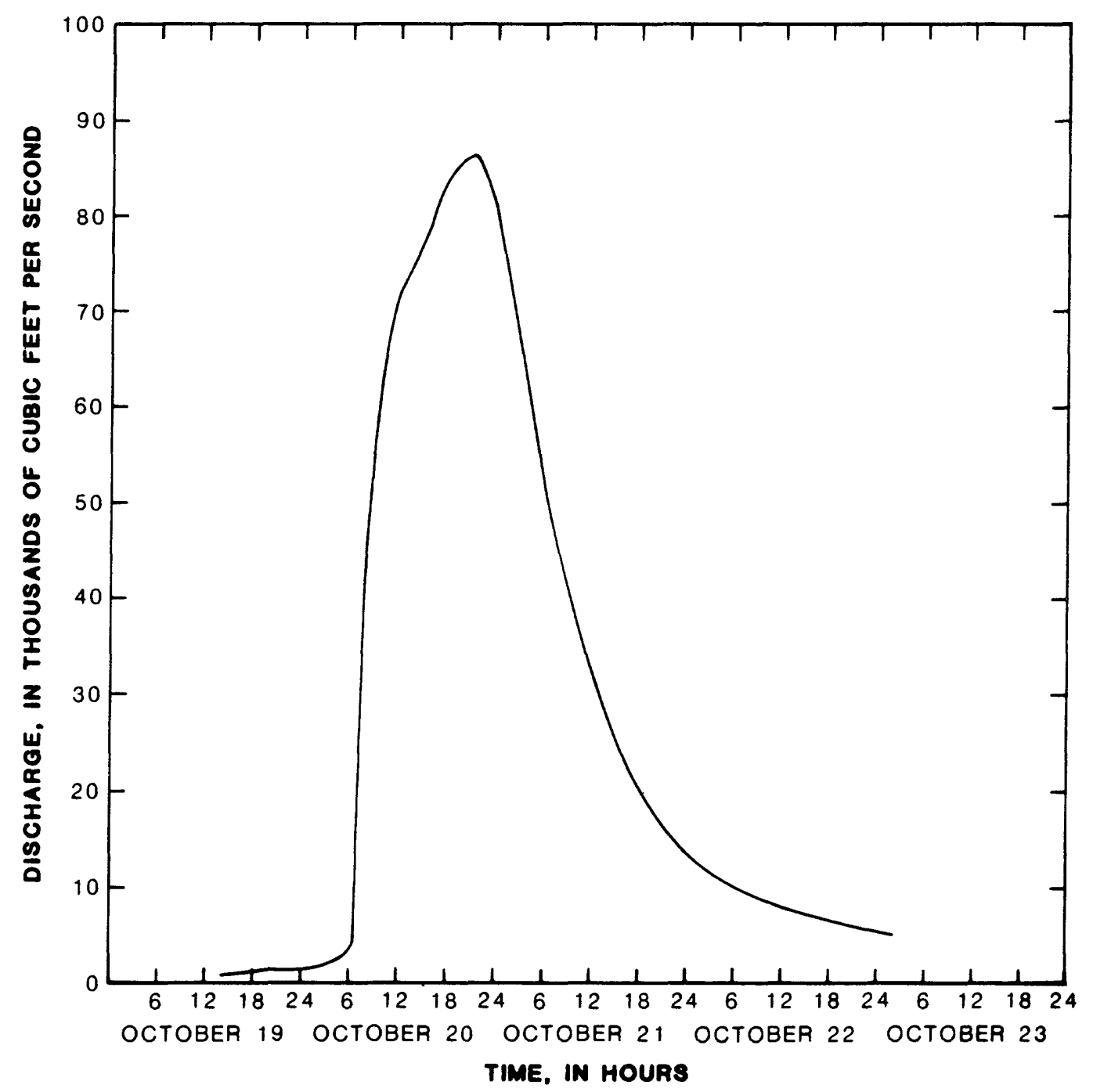

Figure 6.--Discharge hydrograph at U.S. Geological Survey gaging station on Deep Red Run at Randlett, Oklahoma, flood of October 17-23, 1983. 


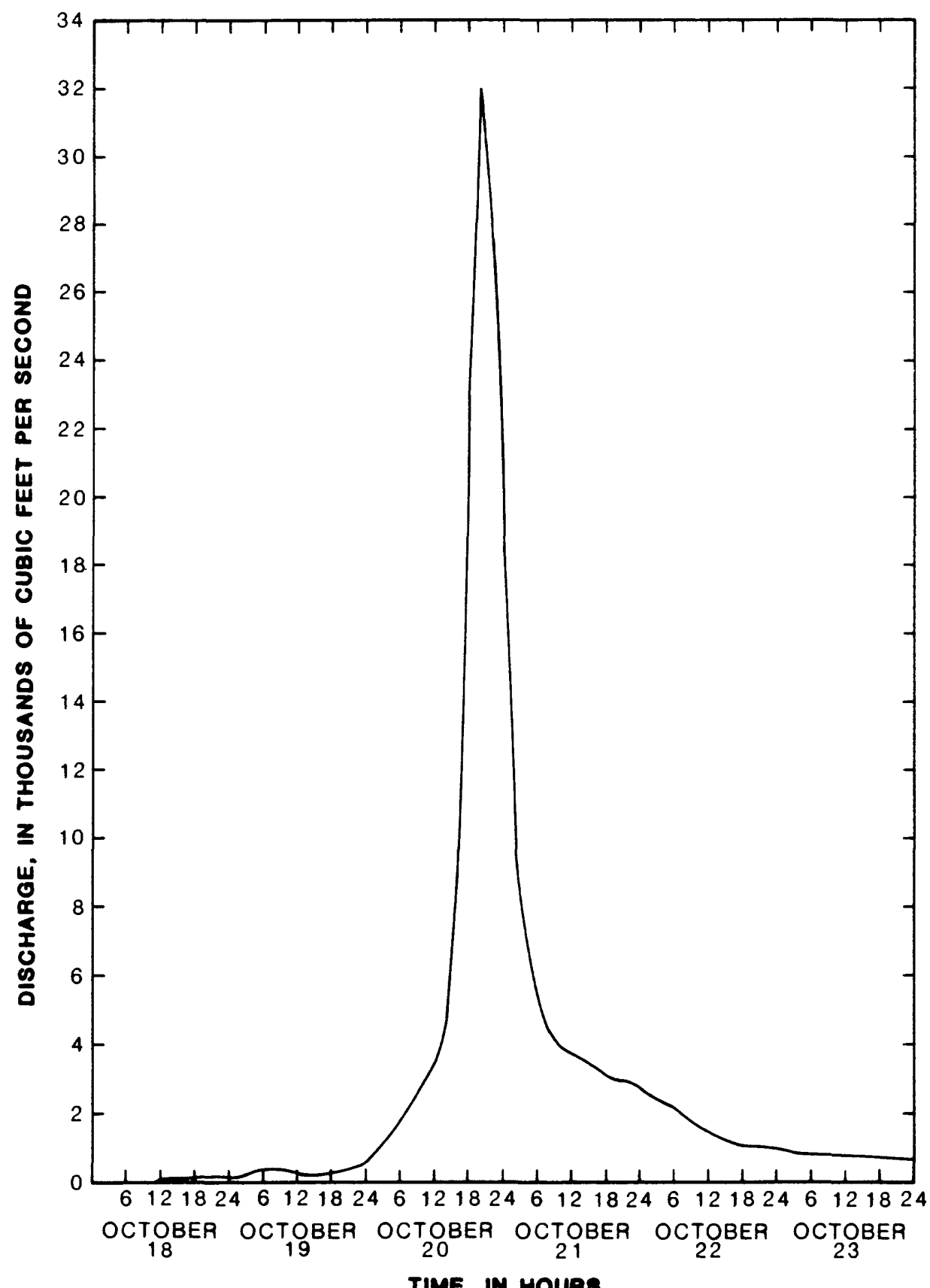

TIME. IN HOUAS

Figure 7.--Discharge hydrograph at U.S. Geological gaging station on Cottonwood Creek near Navina, Oklahoma, flood of October 17-23, 1983. 
Record high flows were recorded along the main stem of the Washita River below Carnegie. However, because streamflow is regulated at many locations in the Washita River basin by both controlled and uncontrolled spillways, hydrograph data for this basin are not shown.

Hydrograph data given in this report show the stream response to rainfall in specific basins in relation to the rainfall distribution in the study area (fig. 4).

\section{FLOOD DAMAGES}

Central and southwest Oklahoma was declared a flood-disaster area shortly after a Presidential declaration for drouaht-relief assistance over much of the same area. A 16-county area was affected by the floodwaters.

Over 250 families received $\$ 580,900$ in disaster-relief grants for single-family homes and 98 claims totaling $\$ 934,200$ were paid through the flood-insurance program. The Small Business Administration reports that 72 loans totaling $\$ 622,000$ were granted as a result of the flood.

A total of $\$ 2,362,900$ in loans for farm homes was granted to 120 individuals according to Farm and Home Administration officials in Dallas, Texas. State, county, and local governments received $\$ 7,986,400$ in disaster loans based on Federal Disaster Assistance Administration reports. These funds were for repairs to roads and bridges lost or damaged during the floods. Figure 8 shows road overflow at U.S. Highway 77 from Walnut Creek in Purcell, Oklahoma on October 20, soon after the flood crest. Floodflows such as these resulted in road closings at numerous locations in the flood area.

One death occurred in Guthrie as a result of the flood. Flood elevations were not measured at Guthrie during this flood; however, flood discharge measured 3 miles upstream was the highest since 1949.

\section{MAGNITUDE AND FREQUENCY OF FLOODING}

Knowledge of the maqnitude and probable frequency of flood recurrence is useful in the desian and location of many types of hydraulic structures and in the development of criteria for flood-plain management.

Techniques for deriving flood-frequency relations are described by the U.S. Water Resources Council (1977) and by Thomas and Corley (1977).

For comparison, peak discharges of the October 17-23, 1983 flood, the August 27-28, 1973 flood in north-central Oklahoma, and other previous outstanding floods in Oklahoma are plotted in flgure $>$ against their respective drainage areas. Outstanding floods of Auqust 27-28, 1977, documented by Corley and Huntzinger (1977), are included in figure 9 because these floods occurred within the October 1983 flood study area.

A curve developed by Crippen and Bue (1977) on the basis of maximum known floods in the United States defines their approximate upper limit through 1974. The other curve shown here was developed by Crippen and Bue 


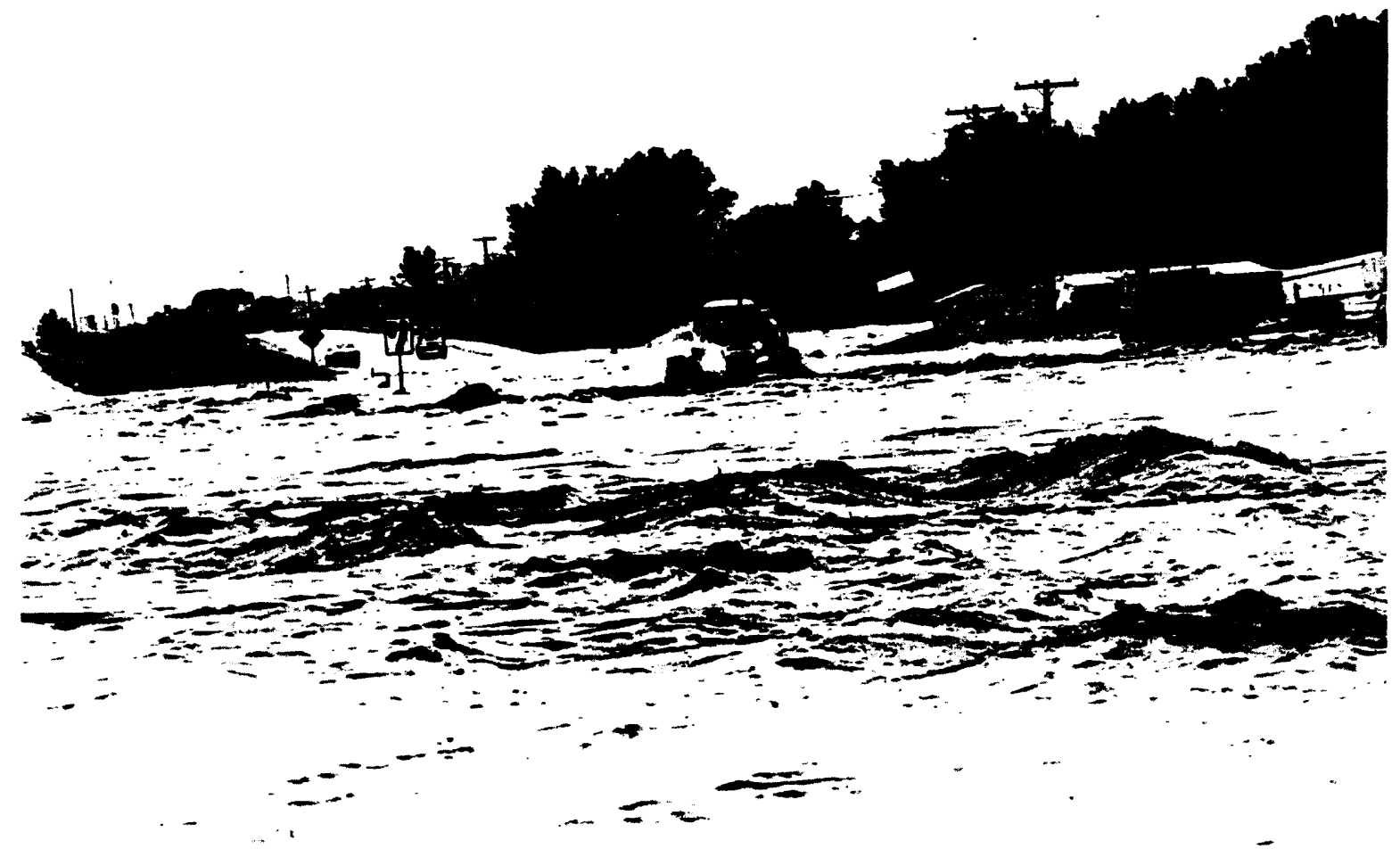

Figure 8.--Vlew looking south toward U.S. Highway 77 bridge over Walnut Creek at Purcell, Oklahoma, Dctober 20, 1983. (Photograph courtesy of "The Purcell Register", Purcell, Oklahoma.) 


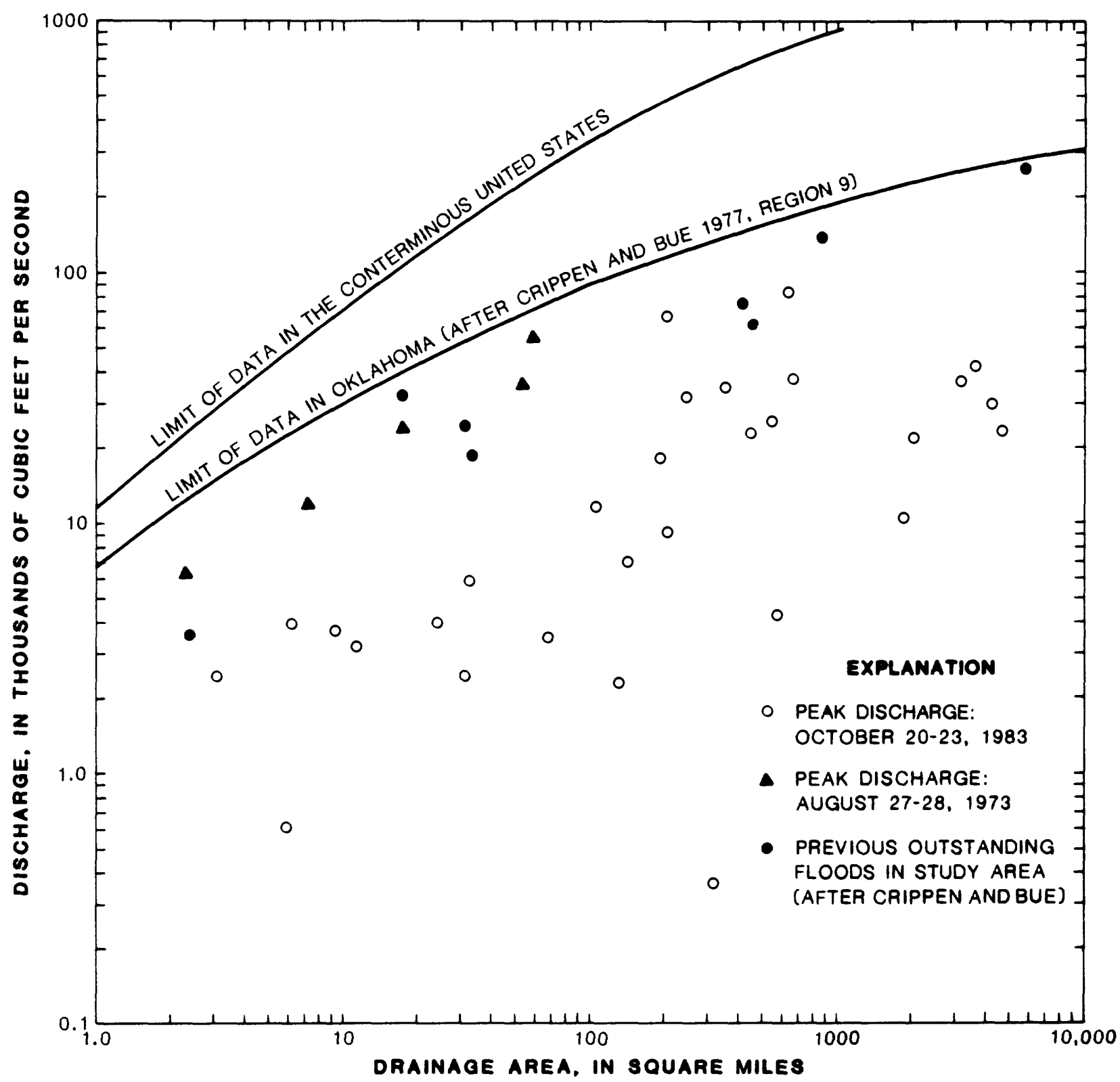

Figure 9.--Comparison of October 17-23, 1983, peak discharges to upper limits of known floods in Oklahoma-Kansas and in the United States. 
(1977) using maximum floods in the Oklahoma, Texas, Missouri, and Kansas region. Peak discharges from Walnut Creek at Purcell and Deep Red Run near Randlett recorded during the October 17-23, 1983 floods compared in magnitude per square mile with those discharges measured during the Auqust 27-28, 1973 floods. However, floodflows determined at remaining locations (table 1) are less in magnitude than both the August 1973 flood and other previous floods in the study area. Data plotted on fiqure 9 indicates that only those streams having over 14 inches of rainfall could be considered an outstanding flood. Peak discharges from drainage areas greater than 10,000 square miles controlled by upstream reservoirs were not plotted on figure 9.

\section{SUMMARY}

Peak discharges were determined during and after flooding following storms of October 17-23, 1983 in central and southwest 0klahoma. These storms were a result of the remains of Hurricane Tico moving through Oklahoma along a frontal system which became stationary extending from the Red River near south-central Oklahoma to southwestern Arkansas. Rainfall amounts exceeded the 100-year 24-hour storm frequency in some areas and was recorded at the Great Plains Aplaries near Chickasha, Oklahoma.

Measurements of floodflows were made at 31 gaging stations and one miscellaneous site. Continuous river stages were collected at 30 sites and where maximum storm-rainfall depth occurred, discharge hydrographs and rainfall mass curves are provided.

Peak discharges recorded as a result of the nctoher 17-23, 1983 flood were compared with other outstandina floods in Oklahoma. Results show the October 1983 flood can be considered to he outstanding only in the areas of maximum rainfall. When the frequency of the flood magnitude was determined for all the sites measured, only Walnut Creek at Purcell and Deep Red Run at Randlett (located in the area of maximum rainfall) peak discharges were equal to or greater than the 100-year flood. 


\section{SELECTED REFERENCES}

Bodhaine, G. L., 1968, Measurement of peak discharqe at culverts by indirect methods: U.S. Geoloqical Survey Techniques of Water-Resnurces Investigations, Book 3, chapter A3, $60 \mathrm{p}$.

Corley, C. K., and Huntzinger, T. L., 1977, Flood of August 27-28, 1977, West Cache Creek and Blue Beaver Creek, southwestern Oklahoma: 1J.S. Geological Survey Open-File Report 79-276

Crippen, J. R., and Bue, C. D., 1977, Maximum floodflows in the conterminous United States: U.S. Geological Survey Water-Supply Paper 1887, 52 p.

Crawford, K. C., 1983 Monthly report of river and flood conditions: National Weather Service Interim Flood Report, October 1983, 3 p.

Dalrymple, Tate, and Benson, M. S., 1967, Measurement of peak discharge by slope-area method: U.S. Geological Survey Techniques of Water-Resources Investigations, Book 3, chapter A2, $12 \mathrm{p}$.

Hulsing, Harry, 1968, Measurement of peak discharge at dams by indirect method: U.S. Geological Survey Techniques of Water-Resources Investigations, Book 3, chapter A5, 29 p.

Hershfield, D. M., 1961, Rainfall frequency atlas of the United States for duration from 30 minutes to 24 hours and return periods from 1 to 100 years: U.S. Weather Bureau Technical Paper 40, $61 \mathrm{p}$.

Matthai, H. F., 1967, Measurement of peak discharge at width contractions by indirect methods: IJ.S. Geological Survey Techniques of Water-Resources Investigations, Book 3, chapter A4, 44 p.

Thomas, W. 0., Jr., and Corley, R. K., 1977, Techniques for estimatina flood discharges for Oklahoma streams: U.S. Geological Survey

Water-Resources Investigations $77-54,170 \mathrm{p}$.

U.S. Water Resources Council, 1981, Guidelines for determinina floodflow frequency: Washington, D.C., U.S. Water Resources Council Bulletin 17B, $163 \mathrm{p}$. 